\title{
Analysis of Economic and Environmental Welfare in the Context of Circular Economy
}

\author{
Jelena Stankevičiené $\dot{1}^{1}$, Marta Nikanorova ${ }^{2}$ \\ Faculty of Business Management, Vilnius Gediminas Technical University, Vilnius, Lithuania \\ E-mails: ${ }^{1}$ jelena.stankeviciene@vgtu.lt; ${ }^{2}$ marta.nikanorova@vgtu.lt (corresponding author)
}

Received 10 May 2017; accepted 11 April 2017

\begin{abstract}
The concept of circular economy is alternative to linear economy, which places sustainability in the center of the interest. The circular economy focuses on environmental, resource efficiency, "no waste" approach, social factors and promotes the co-existing of healthy economy together with environmental health. The purpose of the article is to propose a concept of economic and environmental welfare in the context of circular economy, apply and provide empirical evidence based on economic data of Baltic Sea Region countries. The article includes the observation of environmental aspect and resource efficiency in Baltic Sea Region including green energy, renewable resources, waste management, economic indicators, as well as literature analysis and quantitative analysis. A multi-criteria decision analysis method TOPSIS was used to compare the set of indicators by identifying weights for each criterion. TOPSIS is quite useful method to rank and make selection of a number of indicators. By the result, the Baltic Sea Region countries are scored by the economic and environmental welfare in the context of circular economy.
\end{abstract}

Keywords: Circular economy, waste management, sustainable development, environmental indicators, TOPSIS method.

JEL Classification: Q00, Q0, Q55, R11.

Conference topic: Contemporary Financial Management.

\section{Introduction}

Today the world is challenging the situation of inefficient use of resources, energy and waste management, faces the difficulties to decrease the pollution and maintain "green" environment. The current industrial and business model does not include the global environmental challenges. Business and industry could be one of the most significant participants to change this situation. Circular Economy model itself includes both economic and environmental welfare and sustainability principles shift from the value-added aspects to the core aspects. Business and industry all over the world should be aligned with the environment principle of the Earth and Circular Economy is the principle, which ensures the interconnectivity of economy with the environment, based on the principle of sustainability.

To achieve sustainability there is a need to integrate it in each element of business cycle. However, to improve the environmental situation there is a need to integrate the circular economy model to all business cycles, develop a strategic approach working towards sustainable development and apply it to national, regional and global economy.

The purpose of the article is to propose a concept of economic and environmental welfare in the context of circular economy, apply and provide empirical evidence based on economic data of Baltic Sea Region countries. The concept will help to improve environmental and economic synergy in the specific region, would help to receive empirical data for further analysis and leads to the sustainable development of the specific region.

\section{Circular Economy concept}

A circular economy concept is alternative to linear economy, which is based on production, usage and dispose of the products. The circular economy concept suggest to keep resources in use for as long as possible, extract the maximum value from them whilst in use, then recover and regenerate products and materials at the end of each service life (Stahel 2012). Waste from factories would become a valuable input to another process - and products could be repaired, reused or upgraded, instead of thrown away. It means, that the function of resources used in linear economy will be transformed, as the linear economy includes the "take-make-waste" industrial model (Bechtel et al. 2013), which is inefficient and harmful to environment and ecology. It could potentially help to resolve the sustainability challenge

(C) 2017 J. Stankevičienè, M. Nikanorova. Published by VGTU Press. This is an open-access article distributed under the terms of the Creative Commons Attribution (CC BY 4.0) License, which permits unrestricted use, distribution, and reproduction in any medium, provided the original author and source are credited. 
and support organizations moving towards sustainability by reducing resource extraction and waste streams, leading to decreased environmental impairment.

The circular economy concept originates from eco-industrial development (EID) theory and thought and is based on the 'win - win' philosophy that a healthy economy and environmental health can co-exist. (Geng, Doberstein 2008). It incorporates myriad strategies to achieve greater efficiency through economies of systems integration. Partnerships amongst businesses to meet common service, transportation and infrastructure needs are encouraged. The policy potentially adds value to businesses and communities by optimizing the use of energy, materials and community. The concept of circular economy is represented in Figure 1.

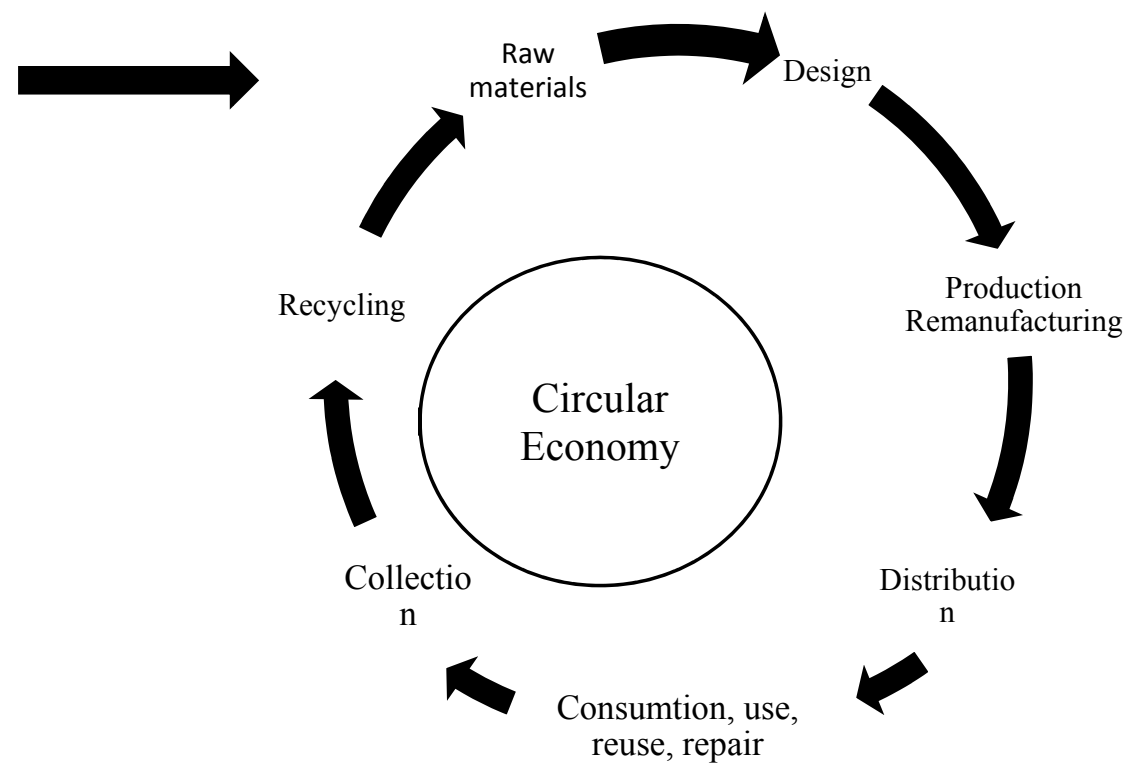

Fig. 1. The concept of Circular Economy (Source: European Commission 2014)

Adopting a circular business model that seeks to sustain the planet could present an attractive win-win-win situation for society, the environment and the company itself. In the long-run, this transformation could offer an essential competitive advantage as CE claims to create more value from resources, support companies in meeting changing market requirements, lowering environmental costs, increasing consumer convenience and securing supplies (Preston 2012). Despite of that, companies adopting a CE could also benefit from savings in material and energy costs, a decrease in resource dependence (e.g. through reusing and re-marketing goods), an improvement in customer interaction and a reduce in warranty use by switching to longer-lasting products.

Circular economy brings significant benefits not only for particular company or industry. It makes a contribution to whole society in general, improving ecology and promoting sustainable development. Efficient use of resources and zero waste may lower the need of resource extraction; by this, the problem of resource scarcity could be alleviated. In addition, by integrating "zero waste" strategy in value chain and business cycle would help to lower the pollution and improve ecological situation (EMF Ellen MacArthur Foundation 2012).

Circular economy will be beneficial to society and to the economy as a whole (Andersen 2007). Benefits will be obtained not only by minimizing use of the environment as a sink for residuals but - perhaps more importantly - by minimizing the use of virgin materials for economic activity. Intuitively, the potential benefits seem straightforward, but it is important to stress that the perspective prevailing within the circular economy approach is, in fact, based on physical rather than economic observations.

According to Ghisellini (Ghisellini et al. 2016), the circular economy is not only the approach of "zero waste" strategy. If circular economy would be considered only as an approach to efficient resource usage and appropriate waste management it could fail. Circular economy is about sustainable development including all the targets of sustainability: social, economic and environmental.

The circular economy is quite new approach to be widely integrated in industry and business. Today many scientists are discussing about the establishing the measurements of circular economy and appropriate indicators to be analyzed because of diversity of different structure of economy, industries, socio-economic climate. The strategy of circular economy should be implemented on national level taking into consideration of socio-economic and environmental aspects of a particular country based on the principle of the global challenges. What is more, there are barriers to refuse "take-make-waste" approach of linear economy in short term perspective. According to Bechtel (Bechtel et al. 2013), it is possible to identify certain barriers: 
1. Technological barriers - there is a need to extend the manufacturing cycle, to create technical and biological material cycles, improve recycling technologies to ensure "zero waste" concept. Moreover, the industry and business need to overtake the recycling system and integrate it also to production cycle.

2. Legal barriers - legal requirements could become a barrier for materials recycling, waste management, replacement of certain materials and etc.

3. Economic barriers - the profit remains the aim of the business and positive return on investment is required to re-organize the company. To re-organize the production, business cycle, the company will require to take risk and face significant costs.

4. Change in mindset - The is a need to rely on new way thinking, to communicate with others in a chain and act according to mindset, to create a new value chain and refuse current paradigm.

There were more barriers presented by Bechtel (Bechtel et al. 2013) such as procurement, as the business would need to create new supply chains, to re-think about material flow, as today there is a limited volume of recycled and reused materials available in the market. Circular economy concept could be represented as a barrier because of its radicalism and complexity to be applied. In addition, customer behavior could be a barrier for circular economy. As business need to change the mindset towards sustainability, the consumers should follow this initiative and create a demand for such goods, re-think their values towards the recycled materials and quality of such goods. Furthermore, quite important barriers are lack of governmental support and collaboration barriers. As the companies should collaborate among themselves and follow the same circular economy approach. It would be impossible to implement circular economy approach to each business cycle element without the collaboration with other companies and motivation from the government side.

\section{Analysis of core environmental and resource efficiency indicators}

The circular economy indicator system requires inputs from three major dimensions - social, economic and environmental. Thus, in this article the environmental and resource efficiency dimensions analyzed in the concept of circular economy that is why the social indicators are not included in the analysis. Today the scientists continue discussions regarding indicators system to evaluate environmental welfare and resource efficiency in the context of circular economy. Different proposals applied to particular countries economy and it is specific. While creation of the set of indicators, important is to pay attention on the specific of the economy of the selected region, to pay attention on the environmental challenges the region faces (Geng et al. 2012; Su et al. 2013).

The European Union contributes to global environmental, usage of "green" energy, resource efficiency challenges by implementing Horizon 2020 programme (European Commission 2016b). Horizon 2020 is the biggest EU research and innovation programme starting from 2014. Horizon 2020 includes energy efficiency problems, such as: reducing energy consumption, alternative fuels and mobile energy sources, low cost and low carbon electricity supply, new knowledge and technologies. Also, Horizon 2020 includes smart, green, integrated transport and resource efficiency (European Commission 2014).

Also, European Union has developed Strategy for Sustainable Development, which aim is to develop actions to achieve a continuous long-term improvement of seven key priority challenges many of which are predominantly environmental (including climate change and clean energy, sustainable transport, sustainable consumption and production, or the conservation and management of natural resources).

The economic and environmental indicators could be divided into four groups: resource efficiency, environmental, economic and waste management. According to $\mathrm{Li}$ ( $\mathrm{Li}$ et al. 2010) Resource efficiency indicators include energy production, consumption and productivity aspects. Group of environmental indicators include implementation of green energy and pollution. Economic indicators include generated value, market diversity etc. The system developed based on Chinese economy, and because of it, some barriers appear during implementation of this system to European Economy. The indicators for the research are collected based on Horizon 2020 and European Union Strategy for Sustainable Development programmes to identify environmental and economic welfare in European region in the context of circular economy.

\section{The idea of MCDA Method TOPSIS}

Multi-criteria Decision Aid is simply a process of decision-making where criteria could be found out. This method attracts by using a well-structured framework to evaluate a criteria by the setting weights, ranks to the criteria in order to establish an importance of all the criteria in the solving problem of decision-making. In fact, MCDA do not necessary will provide the only one right solution to the problem. It happens so, that using MCDA method a decision maker would be well oriented between the different alternatives, so it leads to the choice of decision maker between the provided possible solutions by the method.

MCDA could provide the best decision between the possible alternatives or the final solution could be grouped by the several groups of preference, by ranking or classifying them (Chen 2006). By the implementing MCDA methods, the decision maker would always have the choice of the most suitable solution of the problem, would gather 
all the possible outcomes of the alternatives as it is represented in Table 1. Table 1 represents the structure of MCDA problem, where $\mathrm{A}=\left\{\mathrm{A}^{1}, \mathrm{~A}^{2}, \ldots, \mathrm{A}^{\mathrm{i}}, \ldots, \mathrm{A}^{\mathrm{n}}\right\}$ is the set of alternatives and $\mathrm{Q}=\{1,2, \ldots, \mathrm{j}, \ldots, \mathrm{q}\}$ is the set of criteria. On the basis of this, MCDA methods helps the decision makers to be well oriented in the possible alternative impacts on the decision. Methods of MCDA could be differ as well in the such cases as the choice of criteria, weights estimation, mathematical tools, so it is important to choose the right method before the evaluating the alternatives (Dytczak et al. 2008)

Table 1. The structure of MCDA problem (Source: Cheng 2006)

\begin{tabular}{|c|c|c|c|c|c|c|c|}
\hline & \multicolumn{6}{|c|}{ Alternatives } \\
\hline & & $A^{1}$ & $A^{2}$ & $\ldots$ & $A^{i}$ & $\ldots$ & $A^{n}$ \\
\hline \multirow{6}{*}{ 苟 } & $T$ & & & & $T$ & & \\
\hline & 2 & & & & 1 & & \\
\hline & $\ldots$ & & & & $\downarrow$ & & \\
\hline & $j$ & E & E & $\overline{-}$ & $-c_{j}^{j}$ & & \\
\hline & ... & & & & & & \\
\hline & $q$ & & & & & & \\
\hline
\end{tabular}

MCDA has a wide range of the advantages. It helps to find possible solutions of the problems, could help to classify the solutions to the acceptable and not acceptable. What is more, MCDA helps to develop a whole framework for decision making, which would be based on logic and mathematically proved. What is more, MCDA could help to identify relevant and non-relevant data to the problem solving that would be evaluated. Evaluation and comparison of the alternatives - one of the basic part of MCDA. All this lead to the obtaining of the right decision, evaluation of the problem from the different edges, taking in the account all possible alternatives and outcomes (Montis, Toro 2000).

To sum up, MCDA helps a lot to make the decisions in the own opinion of the decision maker. It helps to develop criterion, that are evaluated, weighted that shows the importance of each in the decision, as well the final result that shows the evaluation of the all possible outcomes of the alternatives.

TOPSIS (Technique for Order Preference by Similarity to Ideal Solution) belongs to MCDA group and is one of the most popular methods is being used in different scientific fields. The basic idea of the method is that the best alternative would be the closest to the best solution and far away from the worst solution. In other words, TOPSIS Method measures the distance to the ideal solution, or the shortest geometric distance (Sarkar 2013). What is more, the TOPSIS method includes weights for criterion, requires a set of alternatives and normalization for the TOPSIS Method. (Jahanshahloo et al. 2006).

TOPSIS method is widely used in different scientific fields. For example, TOPSIS was used to assess the sustainability of government bond funds (Bilbao-Terol et al. 2014), Sustainability reporting in energy companies (Ergüden, Çatlioğlu 2016). Also, TOPSIS method was used to establish the efficiency ranking method in the case of Indian bank (Chitnis, Vaidya 2016), to prioritize critical success factors in pharmaceutical industry (Mehralian et al. 2016) and used to evaluate Ecological-Economic efficiency of green Technology innovation in strategic emerging industries (Sun et al. 2017).

According to the literature review, it is not enough to apply a single index or indicator to measure country's environmental welfare, waste management or sustainability in the context of circular economy. A wide range of different indicators and measurements needed to be analyzed. That is why, TOPSIS method was selected to evaluate environmental aspect of a country. All indicators are well-organized and systemized and on the basis of complex evaluation are represented by the "best" scores or high scores, that shows a closeness to the right decision and "bad" scores or low scores, which show in opposite way - which show the distance to the wrong decision.

The beginning of applying TOPSIS method starts with the decision matrix preparation, assuming that there are $n$ evaluation indicators, and evaluation indicator sets have $m$ subsets, the evaluation value of indicator $j$ in subset $i$ is aij. Decision matrix (Byun, Lee 2005):

$$
A=\left(a_{i j}\right)_{m^{*} n}=\left[\begin{array}{ccc}
a_{11} & \cdots & a_{1 n} \\
\vdots & \ddots & \vdots \\
a_{m 1} & \cdots & a_{m n}
\end{array}\right]
$$

where: element $a_{m n}$ represents the value of the alternative. 
The second step is TOPSIS normalization (Byun, Lee 2005):

$$
\widetilde{r_{i j}}=\frac{r_{i j}}{\sqrt{\sum_{j=1}^{n} r_{i j}^{2}}},
$$

where: $i=1, \ldots ., m ; j=1, \ldots ., n$.

As TOPSIS can analyze data with different numeric values $\left(r_{i j}\right)$, to systemize it there is a need for normalization. Once the data is normalized, each criterion should be multiplied by the weight. There are different types how to establish the weight for TOPSIS method, but for this particular case the equal weight was selected for each criterion to create an equality of the importance of each criterion. Each criterion should be multiplied by the establish weight.

$$
v_{i j}=w_{i j} * r_{i j}
$$

where: $i=1, \ldots . ., m ; j=1, \ldots ., n$.

TOPSIS method includes two categories of the solution as well - the best hypothetical solution $V^{*}$ and the worst hypothetical solution $V^{-}$(Podviezko 2011):

$$
\begin{aligned}
& V^{*}=\left\{V_{1}^{*}, V_{2}^{*}, \ldots, V_{m}^{*}\right\}=\left\{\left(\max _{j} \omega_{i} \tilde{r}_{i j} / i \in I_{1}\right),\left(\min _{j} \omega_{i} \tilde{r}_{i j} / i \in I_{2}\right)\right\}, \\
& V^{-}=\left\{V_{1}^{-}, V_{2}^{-}, \ldots, V_{m}^{-}\right\}=\left\{\left(\min _{j} \omega_{i} \tilde{r}_{i j} / i \in I_{1}\right),\left(\max _{j} \omega_{i} \tilde{r}_{i j} / i \in I_{2}\right)\right\},
\end{aligned}
$$

where: $I_{1}$ is the set of indices of the maximizing criteria; $I_{2}$ is the set of indices of the minimizing criteria.

By the estimating the best hypothetical solution, that is represented by $V^{*}$ and the worst hypothetical solution, that is represented by $V^{-}$, there is a need to analyze the data after the multiplying weight by normalized data. By the estimation the best and the worst hypothetical solutions should take in account whether the criterion are minimizing or maximizing.

The Euclidean distance to the best and the worst hypothetical solutions is calculated as follows:

$$
\begin{gathered}
D_{j}^{*}=\sqrt{\sum_{i=1}^{m}\left(\omega_{i} \tilde{r}_{i j}-V_{i}^{*}\right)^{2}} \\
D_{j}^{-}=\sqrt{\sum_{i=1}^{m}\left(\omega_{i} \tilde{r}_{i j}-V_{i}^{-}\right)^{2}}
\end{gathered}
$$

And the cumulative criterion of the method $C_{j}^{*}$ for each alternative $\mathrm{j}$ is calculated as follows:

$$
C_{j}^{*}=\frac{D_{j}^{-}}{D_{j}^{*}+D_{j}^{-}}(j=1,2, \ldots, n),\left(0 \leq C_{j}^{*} \leq 1\right) .
$$

Cumulative criterion of the method $C_{j}^{*}$ shows the best alternative (Pavić, Novoselac 2013), which distance to the best hypothetical solution is shorter and shows the worst alternative, which distance to the worst hypothetical solution is the smallest.

\section{The research object selection and data collection}

The Baltic Sea Region was represented by European Council in 2009 (European Commission 2016a) by the framework, according to which there is implemented a strategy for improving environmental condition, transport and energy interconnections as well as facilitating the development of competitive markets across borders and common networks for research and innovation. The European Union Strategy for the Baltic Sea Region (EUSBSR) is the first macro-regional strategy in Europe. It aims at reinforcing cooperation within this large region in order to face several challenges by working together as well as promoting a more balanced development in the area. The aim of the strategy is to bring together the initiatives in different sectors (growth, sustainable development etc.) as well as promoting cooperation between stakeholders in Baltic Sea Region. The Strategy also promotes flagships in the Baltic Sea Region. These flagships have a macro-regional impact and start from joint initiatives involving partnership from different countries. The EU member states involved in the EUSBSR are Sweden, Denmark, Estonia, Finland, Germany, Latvia, Lithuania and Poland. The statistical data of these countries included in the analysis from European Statistical 
Database - Eurostat (data of 2013-2014 years). The environmental, resource efficiency and economic indicators have been collected and systemized in Table 2 and Table 2.1. In Table 2 the Economic and Environmental Indicators are represented for Sweden, Denmark, Estonia and Finland. The Economic and Environmental Indicators are divided into four groups: Waste Management, Environmental Indicators, Economic Indicators and Resource Efficiency. Waste Management group of indicators includes recycling rates of waste and landfill rate of waste. Environmental Indicators group consist of: eco-innovation index, greenhouse gas emissions intensity, share of renewable energy in fuel consumption and final energy consumption. Economic Indicator group includes: energy production/consumption per GDP, renewable energy production/consumption per GDP, value added of non-financial business activity. Resource Efficiency group consists of energy/resource productivity, renewable energy consumption/production, electricity generated from renewable resources.

Table 2. Environmental and Economic indicators of Baltic Sea Region

(Source: created by authors based on Eurostat Database 2016)

\begin{tabular}{|c|c|c|c|c|c|c|c|c|}
\hline \multirow{2}{*}{$\begin{array}{l}\text { Economic and Environmental Indicators } \\
\text { Waste Management }\end{array}$} & \multicolumn{2}{|c|}{ Sweden } & \multicolumn{2}{|c|}{ Denmark } & \multicolumn{2}{|c|}{ Estonia } & \multicolumn{2}{|c|}{ Finland } \\
\hline & 2013 & 2014 & 2013 & 2014 & 2013 & 2014 & 2013 & 2014 \\
\hline Recycling rate of municipal waste $\%$ & 48.70 & 49.90 & 43.20 & 45.10 & 17.90 & 31.10 & 32.50 & 32.50 \\
\hline Recycling rate of e-waste $\%$ & 64.90 & 52.50 & 37.60 & 42.30 & 27.80 & 30.40 & 36.30 & 42.40 \\
\hline $\begin{array}{l}\text { Landfill rate of waste excluding major } \\
\text { mineral wastes } \%\end{array}$ & 9.00 & 8.00 & 6.00 & 6.00 & 74.00 & 80.00 & 11.00 & 17.00 \\
\hline \multicolumn{9}{|l|}{ Environmental indicators } \\
\hline Eco-innovation index & 138.00 & 123.00 & 129.00 & 185.00 & 72.00 & 74.00 & 138.00 & 135.00 \\
\hline $\begin{array}{l}\text { Share of renewable energy in gross final } \\
\text { energy consumption \% }\end{array}$ & 52.00 & 52.60 & 27.30 & 29.20 & 25.60 & 26.50 & 36.70 & 38.70 \\
\hline $\begin{array}{l}\text { Greenhouse gas emissions intensity of } \\
\text { energy consumption }\end{array}$ & 80.70 & 79.30 & 84.90 & 80.70 & 95.90 & 94.50 & 85.40 & 77.00 \\
\hline $\begin{array}{l}\text { Share of renewable energy in fuel } \\
\text { consumption of transport \% }\end{array}$ & 17.00 & 19.20 & 5.70 & 5.80 & 0.20 & 0.20 & 9.60 & 21.60 \\
\hline \multicolumn{9}{|l|}{ Economic Indicators } \\
\hline Environmental tax revenues & 5.51 & 5.18 & 8.92 & 8.18 & 8.09 & 8.28 & 6.71 & 6.57 \\
\hline Energy taxes per GDP & 0.02 & 0.00 & 0.02 & 0.02 & 0.02 & 0.02 & 0.02 & 0.02 \\
\hline Energy consumption per GDP & 13.80 & 13.87 & 18.41 & 19.62 & 6.58 & 6.71 & 8.24 & 8.39 \\
\hline Energy production per GDP & 12.56 & 12.68 & 15.71 & 16.80 & 3.34 & 3.24 & 11.30 & 11.38 \\
\hline $\begin{array}{l}\text { Renewable energy consumption per } \\
\text { GDP }\end{array}$ & 25.51 & 25.06 & 59.77 & 59.81 & 22.19 & 21.99 & 20.51 & 20.23 \\
\hline Renewable energy production per GDP & 25.98 & 25.97 & 83.87 & 84.36 & 16.83 & 15.93 & 20.48 & 20.41 \\
\hline $\begin{array}{l}\text { Value added of non-financial business } \\
\text { economy }\end{array}$ & 214595.30 & 214126.20 & 124126.60 & 127418.50 & 9890.50 & 10485.8 & 86344.8 & 87139.00 \\
\hline \multicolumn{9}{|l|}{ Resource Efficiency } \\
\hline Energy productivity & 7.80 & 8.10 & 14.00 & 15.10 & 2.50 & 2.60 & 5.50 & 5.40 \\
\hline Resource productivity & 1.47 & 1.46 & 1.67 & 1.70 & 0.70 & 0.74 & 0.89 & 0.97 \\
\hline $\begin{array}{l}\text { Electricity generated from renewable } \\
\text { sources }\end{array}$ & 61.80 & 63.30 & 43.10 & 48.50 & 13.00 & 14.60 & 30.90 & 31.40 \\
\hline Renewable energy consumption & 17082.60 & 17265.80 & 4329.30 & 4434.70 & 851.20 & 858.90 & 9912.20 & 10155.20 \\
\hline Energy production & 34683.20 & 34133.70 & 16466.20 & 15791.80 & 5653.30 & 5832.30 & 18000.0 & 18054.90 \\
\hline Renewable energy production & 16769.50 & 16659.80 & 3084.90 & 3144.00 & 1122.20 & 1186.00 & 9929.80 & 10068.00 \\
\hline
\end{tabular}

In Table 2.1. the statistical data are represented for Germany, Latvia, Lithuania and Poland. The Economic and Environmental Indicators are represented in the same format as in Table 2. The data is divided in four groups for each country (during the period of 2013-2014 years): Waste Management, Environmental Indicators, Economic Indicators and Resource Efficiency. 
Table 2.1. Environmental and Economic indicators of Baltic Sea Region

(Source: created by authors based on Eurostat Database 2016)

\begin{tabular}{|c|c|c|c|c|c|c|c|c|}
\hline \multirow{2}{*}{$\begin{array}{l}\text { Economic and Environmental } \\
\text { Indicators } \\
\text { Waste Management }\end{array}$} & \multicolumn{2}{|c|}{ Germany } & \multicolumn{2}{|c|}{ Latvia } & \multicolumn{2}{|c|}{ Lithuania } & \multicolumn{2}{|c|}{ Poland } \\
\hline & 2013 & 2014 & 2013 & 2014 & 2013 & 2014 & 2013 & 2014 \\
\hline $\begin{array}{l}\text { Recycling rate of municipal waste } \\
\%\end{array}$ & 63.80 & 65.60 & 25.90 & 27.00 & 27.80 & 30.50 & 24.20 & 32.30 \\
\hline Recycling rate of e-waste $\%$ & 35.60 & 36.00 & 27.80 & 26.40 & 43.80 & 64.60 & 28.10 & 25.80 \\
\hline $\begin{array}{l}\text { Landfill rate of waste excluding } \\
\text { major mineral wastes } \%\end{array}$ & 10.00 & 10.00 & 40.00 & 29.00 & 58.00 & 48.00 & 30.00 & 27.00 \\
\hline \multicolumn{9}{|l|}{ Environmental indicators } \\
\hline Eco-innovation index & 132.00 & 134.00 & 52.00 & 72.00 & 66.00 & 71.00 & 42.00 & 63.00 \\
\hline $\begin{array}{l}\text { Share of renewable energy in gross } \\
\text { final energy consumption } \%\end{array}$ & 12.40 & 13.80 & 37.10 & 38.70 & 23.00 & 23.90 & 11.30 & 11.40 \\
\hline $\begin{array}{l}\text { Greenhouse gas emissions intensity } \\
\text { of energy consumption }\end{array}$ & 97.80 & 95.80 & 84.60 & 82.90 & 110.40 & 106.60 & 90.70 & 90.10 \\
\hline $\begin{array}{l}\text { Share of renewable energy in fuel } \\
\text { consumption of transport } \%\end{array}$ & 6.40 & 6.60 & 3.10 & 3.20 & 4.60 & 4.20 & 6.00 & 5.70 \\
\hline \multicolumn{9}{|l|}{ Economic Indicators } \\
\hline Environmental tax revenues & 5.38 & 5.24 & 8.60 & 9.26 & 6.04 & 6.13 & 7.50 & 7.82 \\
\hline Energy taxes per GDP & 0.02 & 0.02 & 0.02 & 0.02 & 0.02 & 0.01 & 0.02 & 0.02 \\
\hline Energy consumption per GDP & 12.99 & 14.00 & 5.92 & 6.08 & 7.30 & 7.48 & 6.24 & 6.67 \\
\hline Energy production per GDP & 23.44 & 24.39 & 10.64 & 9.92 & 24.75 & 24.60 & 5.59 & 6.15 \\
\hline $\begin{array}{l}\text { Renewable energy consumption } \\
\text { per GDP }\end{array}$ & 84.62 & 82.58 & 14.16 & 14.64 & 28.87 & 28.65 & 46.12 & 47.84 \\
\hline $\begin{array}{l}\text { Renewable energy production per } \\
\text { GDP }\end{array}$ & 83.92 & 81.18 & 10.68 & 9.96 & 27.17 & 26.94 & 46.38 & 51.03 \\
\hline $\begin{array}{l}\text { Value added of non-financial } \\
\text { business economy }\end{array}$ & 1425740.9 & 1531691.5 & 9617.10 & 10086.7 & 12531.2 & 14557.6 & 172212.0 & 181284.40 \\
\hline \multicolumn{9}{|l|}{ Resource Efficiency } \\
\hline Energy productivity & 8.30 & 8.80 & 4.50 & 4.60 & 4.80 & 4.90 & 4.00 & 4.30 \\
\hline Resource productivity & 2.03 & 2.07 & 0.80 & 0.86 & 1.25 & 1.39 & 1.05 & 1.09 \\
\hline $\begin{array}{l}\text { Electricity generated from } \\
\text { renewable sources }\end{array}$ & 25.30 & 28.20 & 48.80 & 51.10 & 13.10 & 13.70 & 10.70 & 12.40 \\
\hline Renewable energy consumption & 33397.40 & 35406.30 & 1611.20 & 1613.10 & 1212.40 & 1277.00 & 8559.40 & 8590.80 \\
\hline Energy production & 120566.30 & 119865.80 & 2143.50 & 2380.50 & 1414.20 & 1487.40 & 70570.50 & 66866.90 \\
\hline Renewable energy production & 33679.50 & 36017.90 & 2137.00 & 2371.20 & 1288.40 & 1358.20 & 8511.50 & 8054.40 \\
\hline
\end{tabular}

The data collected and represented in Table 2 and in Table 2.1 is systemized, normalized according to TOPSIS normalization, maximized and minimized accordingly. TOPSIS method results represented in Table 3.

Table 3. TOPSIS method result represented as Cumulative Criterion (Source: created by author)

\begin{tabular}{c|c|c}
\hline Country & 2013 & 2014 \\
\hline Sweden & 0.4687 & 0.5989 \\
\hline Denmark & 0.3923 & 0.4135 \\
\hline Estonia & 0.1503 & 0.1596 \\
\hline Finland & 0.3345 & 0.3831 \\
\hline Germany & 0.6298 & 0.6451 \\
\hline Latvia & 0.2350 & 0.2576 \\
\hline Lithuania & 0.1820 & 0.2175 \\
\hline Poland & 0.2959 & 0.3043 \\
\hline
\end{tabular}


As the results show, all the countries improved their performance to compare 2013 and 2014 years. According to the TOPSIS method calculation, Sweden almost doubled its performance results in the period of 2013-2014. Sweden results changed by 0.1302 . It is the highest change to compare to the rest countries of Baltic Sea Region. Finland's change is 0.0486 to compare 2013 and 2014 results. The third country according to the highest change is Lithuania. Lithuania in 2014 has improved its result from 0.1820 to 0.2175 and the change is equal to 0.0355 . Denmark and Latvia improved their results by 0.0212 and 0.0226 accordingly. The fifth country by the highest change is Germany, which improved its performance by 0.0153 from 2013 to 2014. Estonia's change is equal to 0.0093 and Poland's change is equal to 0.0084 by the 2014 .

As well, it is possible to look separately on the results of 2013 and 2014 years. Figure 2 provides the results of TOPSIS Method of 2013 by country. The closer point to the center means the highest rate of the country or the closest to the right decision and the taller point from the center indicates the closeness to the wrong decision. In 2013, the highest rate had Germany, Sweden and Denmark. The fourth and fifth are Finland and Poland. Latvia, Lithuania and Estonia had the lowest rate of environmental and economic welfare in 2014 to compare to other Baltic Sea Region.

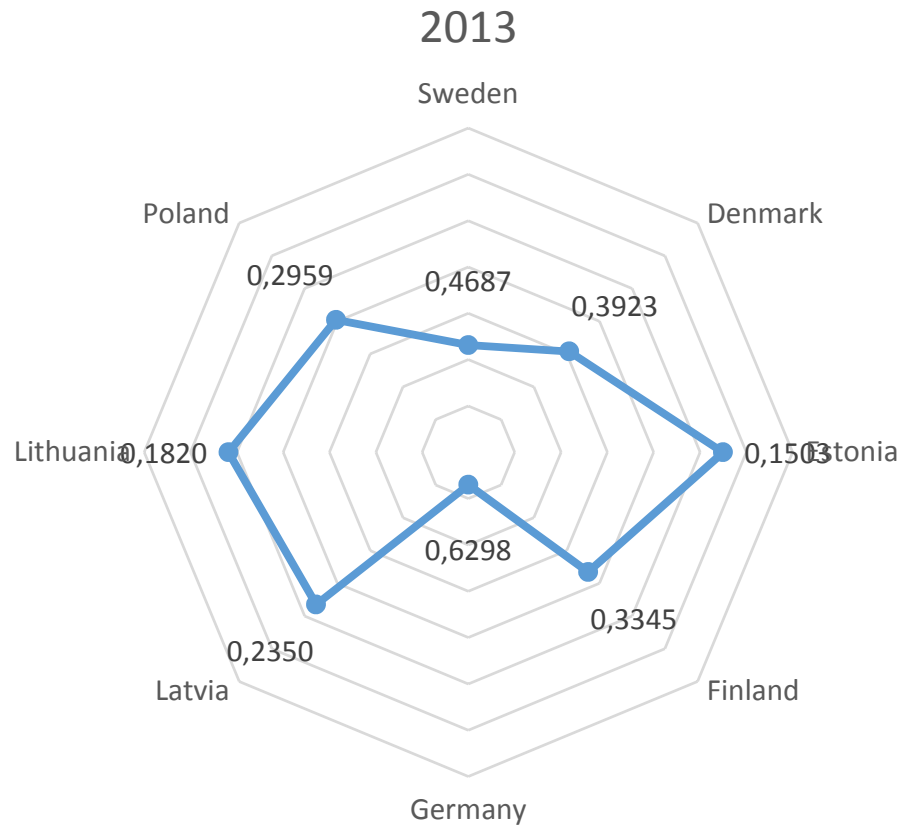

Fig. 2. The results of TOPSIS method by country in 2013 (Source: made by authors)

In 2014, all the countries improved their results in compare to 2013. In Figure 3, it is represented environmental and economic welfare of Baltic Sea Region.

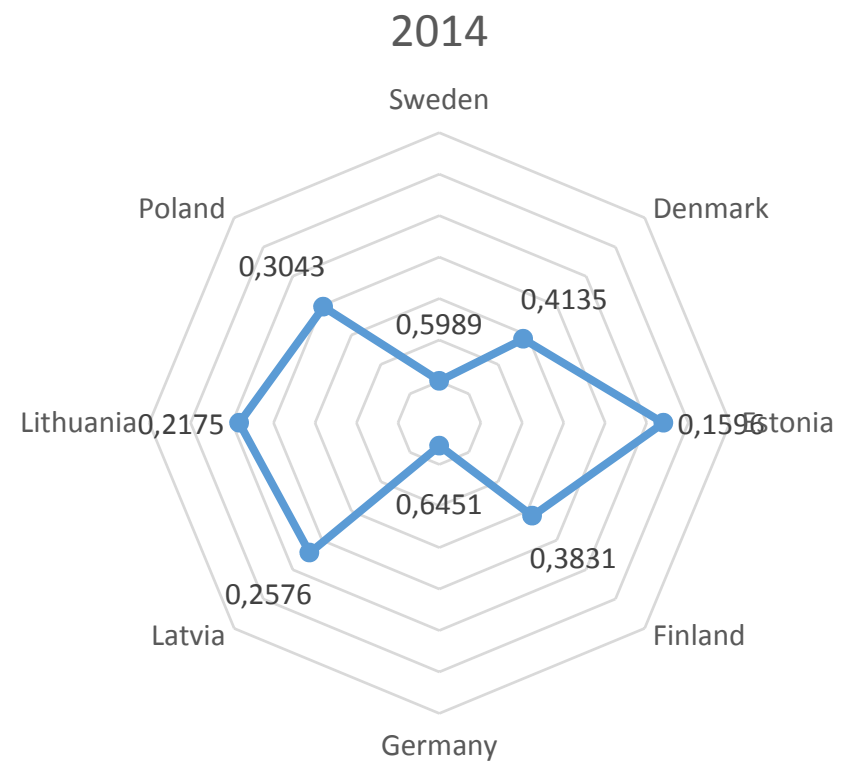

Fig. 3. The results of TOPSIS method by country in 2014 (Source: made by authors) 
According to the results, the highest evaluation have Sweden, Germany and Denmark. Also, Finland and Poland remain in fourth and fifth positions as in 2013. Latvia, Lithuania and Estonia as well hold their position in 2014. To compare the change in environmental and economic welfare of Baltic States, Lithuania had the highest change from 2013 to 2014.

To sum up, according to results, all the countries are moving towards more sustainable environment and economy, some countries make a significant steps to improve the current situation, some countries experience slow movement towards the welfare.

\section{Conclusions}

The circular economy is based on sustainability process that is integrated in all elements of business cycles, promoting "zero waste", resource efficiency and "green" environment promoting "win-win" theory, when healthy economy can co-exist with healthy environment. However, circular economy due its complexity and radicalism cannot easily replace the linear economy. Circular economy is a not only about environment and resource efficiency; it is about sustainable development including all the parts of sustainability: social, economic, environmental.

Economic and environmental indicators were collected according to Horizon 2020 and European Union Strategy for Sustainable Development programmes and systemized in four groups: resource efficiency, environmental, economic and waste management. The Baltic Sea Region countries have been selected for further economic and environmental indicators analysis. This Region have been selected due to European Union Strategy for the Baltic Sea Region programme, which goal is to reinforce cooperation within this large region in order to face several challenges by working together as well as promoting a more balanced development in the area.

Multi-criteria Decision Aid was selected to measure the economic and environmental welfare in circular economy context. This method attracts by using a well-structured framework to evaluate a criteria by the setting weights, ranks to the criteria in order to establish an importance of all the criteria in the solving problem of decision-making. MCDA method TOPSIS was selected, which is widely used different scientific fields to establish the closeness to the best solution.

As a result, eight Baltic Sea Region countries were analyzed and evaluated their environmental and economic welfare using TOPSIS method in the period 2013-2014: Sweden, Denmark, Estonia, Finland, Germany, Latvia, Lithuania and Poland. In 2013, the highest results had Germany (0.6298), Sweden (0.46875) and Denmark (0.3923). In 2014, the highest results had Germany (0.6451), Sweden (0.5989), and Denmark (0.4135). The highest positive change in the period from 2013 to 2014 had Sweden, which could increase the result by 0.1302 . Also, Finland increased its result by 0.0486 and Lithuania, which increased it result by 0.0355 during the 2013-2014. All the countries increased their economic and environmental welfare from 2013 to 2014, according to their possibilities and economic development. It means that European Union programs for sustainable development bring positive results.

The environmental and economic welfare concept helps to measure sustainable development of the region, by the analysis of the empirical data received. The concept is useful to evaluate the synergy of environmental and economic aspects in the concept of circular economy and could be used for scientific, statistical and strategic purposes as by scientists, as well by business, industry and government.

\section{References}

Andersen, M. S. 2007. An introductory note on the environmental economics of the circular economy, Integrated Research System for Sustainability Science and Springer 2: 133-140. https://doi.org/10.1007/s11625-006-0013-6

Bechtel, N.; Bojko, R.; Völkel, R. 2013. Be in the loop: circular economy and strategic sustainable development. School of Engineering. Blekinge Institute of Technology, Sweden.

Bilbao-Terol, A.; Arenas-Parra, M.; Canal-Fernandez, V.; Antomil-Ibias, J. 2014. Using TOPSIS for assessing the sustainability of government bond funds, Omega 49: 1-17. https://doi.org/10.1016/j.omega.2014.04.005

Byun, H. S.; Lee, K. H. 2005. A decision support system for the selection of a rapid prototyping process using the modified TOPSIS method, International Journal of Advanced Manufacturing Technology 26(11-12): 1338-47. https://doi.org/10.1007/s00170-004-2099-2

Cheng, Y. 2006. Multiple criteria decision analysis: classification problems and solutions. University of Waterloo, Ontaria, Canada.

Chitnis, A.; Vaidya, O. S. 2016. Efficiency ranking method using DEA and TOPSIS (ERM-DT): case of an Indian bank, An International Journal 23(1): 135-162. https://doi.org/10.1108/bij-09-2013-0093

Dytczak, M.; Ginda, G.; Pergol, M. 2008. Possibility and benefits of MCDA application for decision making problems support and printing activities. Warsaw University of Technology.

EMF Ellen MacArthur Foundation. 2012. Towards the circular economy [online] Executive Summary [cited 28 January 2017]. Available from Internet: http://www.thecirculareconomy.org/exec-summary

Ergüden, E.; Çatlioğlu, E. 2016. Sustainability reporting practices in energy companies with TOPSIS method, Journal of Accounting and Finance 21: 201-221. 
European Commission. 2014. Towards a circular economy: a zero waste programme for Europe, Communication from the commission to the European Parliament, the Council, The European Economic and Social Committee and the Committee of the Regions. Brussels, Document COM 398: 5.

European Commission. 2016a. European Union strategy for Baltic region [online], [cited 28 January 2017]. Available from Internet: https://www.balticsea-region-strategy.eu/about

European Commission. 2016b. Horizon 2020 [online], [cited 28 January 2017]. Available from Internet: http://eur-lex.europa.eu/legal-content/EN/ALL/?uri=CELEX:52011DC0808

Eurostat database. 2016. Sustainable development Indicators [online], [cited 28 January 2017]. Available from Internet: http://appsso.eurostat.ec.europa.eu/nui/show.do?dataset=nrg_109a\&lang=en

Geng, Y.; Doberstein, B. 2008. Developing circular economy in China: challenges and opportunities for achieving "leapfrog development", International Journal of Sustainable Development and World Ecology 15(3): 231-239. https://doi.org/10.3843/SusDev.15.3:6

Geng, Y.; Fu, J.; Sarkis, J.; Xue, B. 2012. Towards a national circular economy indicator system in China: an evaluation and critical analysis, Journal of Cleaner Production 23: 216-224. https://doi.org/10.1016/j.jclepro.2011.07.005

Ghisellini P.; Cialani C.; Ulgiati, S. 2016. A review on circular economy: the expected transition to a balanced interplay of environmental and economic systems, Journal of Cleaner Production 114: 11-32. https://doi.org/10.1016/j.jclepro.2015.09.007

Jahanshahloo, G. R.; Hosseinzadeh Lotfi, F.; Izadikhah M. 2006. An algorithmic method to extend TOPSIS for decision-making problems with interval data, Applied Mathematics and Computation 175: 1375-1384. https://doi.org/10.1016/j.amc.2005.08.048

Li, H.; Bao, W.; Xiu, C.; Zhang, Y.; Xu, H. 2010. Energy conservation and circular economy in China's process industries, Energy 35: 4273-4281. https://doi.org/10.1016/j.energy.2009.04.021

Mehralian, G.; Nazari, J. A.; Rasekh, H. R.; Hosseini, S. 2016. TOPSIS approach to prioritize critical success factors of TQM: evidence from the pharmaceutical industry, The TQM Journal 28(2): 235-249. https://doi.org/10.1108/TQM-03-2014-0028

Montis, A.; Toro, P. 2000. Criteria for quality assessment of MCDA methods, in $3^{\text {rd }}$ Biennial Conference of the European Society for Ecological Economics, Vienna.

Pavić, Z.; Novoselac, V. 2013. Notes on TOPSIS method, International Journal of Research in Engineering and Science (IJRES) 1(2): 5-12.

Podviezko, A. 2011. Augmenting multi-criteria decision aid methods by graphical and analytical reporting tools. Springer, 236251.

Preston, F. 2012. A global redesign? Shaping the circular economy. Energy, environment and resource governance. London: Chatham House.

Sarkar, A. 2013. A TOPSIS method to evaluate the technologies, International Journal of Quality and Reliability Management 31(1): 2-13. https://doi.org/10.1108/IJQRM-03-2013-0042

Stahel, W. R. 2012. The business angle of a circular economy - higher competiveness, higher resource security and material efficiency. The Product-Life Institut. Geneva, 15.05.12 EMF.

Su, B.; Heshmati, A.; Geng, Y.; Yu, X. 2013. A review of the circular economy in China: moving from rhetoric to implementation, Journal of Cleaner Production 42: 215-227. https://doi.org/10.1016/j.jclepro.2012.11.020

Sun, L.; Miao, C.; Yang, L. 2017. Ecological-economic efficiency evaluation of green technology innovation in strategic emerging industries based on entropy weighted TOPSIS method, Ecological Indicators 73: 554-558. https://doi.org/10.1016/j.ecolind.2016.10.018 